\title{
Square-wave voltammetric determination of rutin in pharmaceutical formulations using a carbon composite electrode modified with copper (II) phosphate immobilized in polyester resin
}

\author{
Kellen Heloizy Garcia Freitas ${ }^{1}$, Orlando Fatibello-Filho ${ }^{2, *}$, Ivanildo Luiz de Mattos ${ }^{3}$ \\ ${ }^{1}$ Department of Chemistry, Federal University of Pará, ${ }^{2}$ Department of Chemistry, Federal University of São Carlos, \\ ${ }^{3}$ Department of Chemistry of Materials, University of Chile
}

\begin{abstract}
A carbon composite electrode modified with copper (II) phosphate immobilized in a polyester resin $\left(\mathrm{Cu}_{3}\left(\mathrm{PO}_{4}\right)_{2}\right.$-Poly $)$ for the determination of rutin in pharmaceutical samples by square-wave voltammetry is described herein. The modified electrode allows the determination of rutin at a potential $(0.20 \mathrm{Vvs} . \mathrm{Ag} /$ $\left.\mathrm{AgCl}\left(3.0 \mathrm{~mol} \mathrm{~L}^{-1} \mathrm{KCl}\right)\right)$ lower than that observed at an unmodified electrode. The peak current was found to be linear to the rutin concentration in the range from $9.9 \times 10^{-8}$ to $2.5 \times 10^{-6} \mathrm{~mol} \mathrm{~L}^{-1}$, with a detection limit of $1.2 \times 10^{-8} \mathrm{~mol} \mathrm{~L}^{-1}$. The response of the electrode was stable, with no variation in baseline levels within several hours of continuous operation. The surface morphology of the modified electrode was characterized by scanning electron microscopy (SEM) and energy dispersive X-ray (EDX) system. The results obtained are precise and accurate. In addition, these results are in agreement with those obtained by the chromatographic method at a $95 \%$ confidence level.
\end{abstract}

Uniterms: Rutin/determination in pharmaceuticals samples. Square-wave voltammetry/determination of rutin. Modified carbon composite electrode/application.

\begin{abstract}
Descreve-se um eletrodo de carbono modificado com fosfato de cobre (II) imobilizado em uma resina de poliéster $\left(\mathrm{Cu}_{3}\left(\mathrm{PO}_{4}\right)_{2}\right.$-Poly) para a determinação de rutina em amostras farmacêuticas por voltametria de onda quadrada. O eletrodo modificado permite a determinação de rutina em potencial $\left(0.20 \mathrm{~V}\right.$ vs $\left.\mathrm{Ag} / \mathrm{AgCl}\left(3,0 \mathrm{~mol} \mathrm{~L}^{-1} \mathrm{KCl}\right)\right)$ menor que o observado em um eletrodo não modificado. Verificou-se que a corrente de pico foi linear com a concentração de rutina na faixa de $9,9 \times 10^{-8}$ a $2,5 \times 10^{-6} \mathrm{~mol} \mathrm{~L}^{-1}$, com um limite de detecção de $1,2 \times 10^{-8} \mathrm{~mol} \mathrm{~L}^{1}$. A resposta do eletrodo foi estável, sem variação significativa dentro de várias horas de operação contínua. A morfologia da superfície do eletrodo modificado foi caracterizada por microscopia eletrônica de varredura (MEV) e pelo sistema de energia dispersiva de raios-X (EDX). Os resultados obtidos foram precisos e exatos. Ademais, estes resultados estão de acordo com aqueles obtidos pelo método cromatográfico a um nível de confiança de $95 \%$.
\end{abstract}

Uniterms: Rutina/determinação em amostras farmacêuticas. Voltametria de onda quadrada/determinação de rutina. Eletrodo compósito de carbono modificado/aplicação.

\section{INTRODUCTION}

Rutin $\left(\mathrm{C}_{27} \mathrm{H}_{30} \mathrm{O}_{16}\right)$ is one of the most abundant flavonoids in the human diet (He, 2007) and concerns the kind of flavonoids, glycoside, commonly found in plants such as Flos Sophorae buds and others species of plants (Chen et al., 2000; Xu, 2007). Rutin is also founded in orange,

\footnotetext{
*Correspondence: O. Fatibello-Filho. Centro de Ciências Exatas e de Tecnologia, Departamento de Química, Universidade Federal de São Carlos. Caixa postal 676, 13.560-970 - São Carlos - SP, Brasil. E-mail: bello@ufscar.br
}

grapefruit, lemon, berries and so forth (Packer, 2001). It has been widely used as a therapeutic agent and more than 130 preparations containing rutin are registered as drugs worldwide (Dapkevicious et al., 1999; Erlund, 2000). Some related investigations show that rutin has a broad range of biological activities, such as anti-inflammatory, anti-tumor and anti-bacterial (Gene et al., 1996; Nuengchamnong et al., 2004).

Due to its importance, several methods for rutin determination based on spectrophotometry (Li et al., 2005), chromatography (Nuengchamnong et al., 2004; Wang 
et al., 2003), and electrochemistry (Franzoi et al., 2009; Santos et al., 2008; Xu, 2007), have been reported. Electrochemical techniques can be used as alternative methods for the determination of rutin because they are simple, fast, and low-cost. Among these, square-wave voltammetry (SWV) was proved to be extremely sensitive for the detection of organic molecules, with low non-Faradaic current, high sensitivity and very low detection limit (Freitas et al., 2010; Freitas, 2010).

The sensitivity, selectivity and operational stability of electrochemical analysis can be enhanced using chemically modified electrodes (CMEs) (Pereira et al., 2002). CMEs have attracted a lot of attention due to the possibility of modifying the electrode surface including composite generation, polymer coating, and so forth. The modification of carbon paste or composite electrodes is an attractive research area in analytical chemistry with potential applications in electroanalysis and chemical sensors (Fatibello-Filho et al., 2000; Freitas et al., 2009; Pereira et al., 2002). The introduction of different compounds into the carbon paste or composite electrode has been demonstrated during in the analysis of numerous organic and inorganic compounds. In recent years, molecular recognition at the surface of solid materials has attracted interest of researchers who are trying to develop functional materials for chemical sensors. The use of nanoparticles, including carbon nanotubes, shows a trend toward improving the applicability (Liu et al., 2010; Yang et al., 2010).

Brett and co-workers studied the electro-oxidation of rutin (Ghica et al., 2005), quercetin (Brett et al., 2003), and catechin (Janeiro et al., 2004) using different voltammetric techniques, and revealed that the various hydroxyl groups of these compounds can be oxidized in different cyclic voltammetric peaks by adsorptioninvolved and $\mathrm{pH}$-dependent transitions. The oxidation mechanisms are very complex due to the formation of multiple products (He et al., 2007; He, 2007). Volikakis and Efstathiou (2000) examined the possibility of determining twelve flavonoids using adsorptive stripping voltammetry in a flow injection system. In their study, carbon paste electrodes based on mixtures of Nujolgraphite and diphenylether-graphite were used. Zu et al. (2006) identified flavanols in leaves by HPLC with diode array detection (DAD).

In the present work, we describe a simple, fast and low-cost square-wave voltammetric method for the determination of rutin in pharmaceutical samples. A modified carbon composite electrode (MCCE) with copper (II) phosphate immobilized in a polyester resin $\left(\mathrm{Cu}_{3}\left(\mathrm{PO}_{4}\right)_{2}-\right.$ Poly) was used for this task.

\section{EXPERIMENTAL}

\section{Apparatus}

All voltammetric measurements were carried out in a single-compartment glass cell with a three electrodes system and degassing facilities for bubbling $\mathrm{N}_{2}$. A modified carbon composite electrode (MCCE) with copper (II) phosphate immobilized in a polyester resin $\left(\mathrm{Cu}_{3}\left(\mathrm{PO}_{4}\right)_{2}-\right.$ Poly) was used as working electrode, $\mathrm{Ag} / \mathrm{AgCl}\left(3 \mathrm{~mol} \mathrm{~L}^{-1}\right.$ $\mathrm{KCl}$ ) as reference electrode, and platinum wire as auxiliary electrode. Square wave and cyclic voltammetric measurements were performed using AUTOLAB PGSTAT-30 (Ecochemie) potentiostat/galvanostat controlled with the GPES 4.0 software.

Physical characterization and electrode surface composition were investigated using a Philips model XL30 TMP scanning electron microscopy (SEM) with energy dispersive X-ray (EDX) system. The equipment was calibrated with metallic nickel.

HPLC was used as the comparative method for the determination of rutin, which was performed using a LC10AT Shimadzu system, with an UV/Vis detector (SPDM10-AVP) set at the wavelength of $257 \mathrm{~nm}$. A Shim-Pack CLC-ODS $(60 \mu \mathrm{m}$ x $150 \mathrm{~mm}, 5 \mu \mathrm{m})$ chromatographic column was used. The mobile phase consisted of a methanol/ acetonitrile/water $(40 / 15 / 45, \mathrm{v} / \mathrm{v} / \mathrm{v})$ solution containing $1.0 \% \mathrm{v} / \mathrm{v}$ formic acid at a flow-rate of $1.0 \mathrm{~mL} \mathrm{~min}^{-1}$, while the injection volume was $30 \mu \mathrm{L}$.

\section{Reagents and solutions}

All solutions were prepared using ultra-purified water supplied by a Milli-Q system (Millipore ${ }^{\circledR}$ ) with resistivity equal to or higher than $18 \mathrm{M} \Omega \mathrm{cm}$. All chemicals used such as sodium phosphate, sodium nitrate, potassium nitrate, sodium chloride, potassium chloride, and phosphoric acid (Merck, Germany), were of analytical reagent grade. Methylethylketone peroxide (MEK peroxide) was purchased from Ibere, Ramires and Cia (Taboão da Serra, SP) and, rutin, graphite powder (1-2 $\mu \mathrm{m})$, and solid paraffin were purchased from Sigma-Aldrich. Polyester resin (Resapol T-208) was acquired from Reichhold (Mogi das Cruzes, SP). Phosphate buffer solutions ( $\mathrm{pH}$ range between 4 and 9), sodium nitrate, potassium nitrate, sodium chloride, and potassium chloride were prepared for the study of the supporting electrolyte in several concentrations.

Rutin working standard solutions $\left(9.9 \times 10^{-8}\right.$ to $\left.2.5 \times 10^{-6} \mathrm{~mol} \mathrm{~L}^{-1}\right)$ were freshly prepared by dilution of a $1.0 \times 10^{-4} \mathrm{~mol} \mathrm{~L}^{-1}$ rutin stock solution in supporting electrolyte. 


\section{Immobilization of $\mathrm{Cu}_{3}\left(\mathrm{PO}_{4}\right)_{2}$ in polyester resin and preparation of the electrode}

$\mathrm{Cu}_{3}\left(\mathrm{PO}_{4}\right)_{2(\mathrm{~S})}$ was prepared by reacting $\mathrm{CuCO}_{3}$. $\mathrm{Cu}(\mathrm{OH})_{2}$ with concentrated phosphoric acid. The immobilization of $\mathrm{Cu}_{3}\left(\mathrm{PO}_{4}\right)_{2}$ was performed using a polyester resin and methylethylketone peroxide as a catalyst. Graphite powder (1-2 $\mu \mathrm{m}$ particle size; Aldrich) and solid paraffin (Aldrich), both of high purity, were used in the preparation of carbon composite.

The immobilization of $\mathrm{Cu}_{3}\left(\mathrm{PO}_{4}\right)_{2}$ in polyester resin $\left(\mathrm{Cu}_{3}\left(\mathrm{PO}_{4}\right)_{2}\right.$-Poly $)$ was achieved using a method similar to that proposed by Pereira and Fatibello-Filho (1998). Five grams of polyester resin were mixed with five grams of $\mathrm{Cu}_{3}\left(\mathrm{PO}_{4}\right)_{2(\mathrm{~S})}$ and $0.3 \mathrm{~mL}$ of methylethylketone peroxide (catalyst). A rigid solid was obtained after three hours, which was initially broken with a hammer and then ground in a Tecnal multiuse mill, model TE 631/1 (Piracicaba, Brazil). Particles smaller than $100 \mu \mathrm{m}$ were selected by sieving on a known mesh sieve.

The MCCE with $\left(\mathrm{Cu}_{3}\left(\mathrm{PO}_{4}\right)_{2}\right.$-Poly) used as working electrode was prepared according to the building method proposed by Freitas and Fatibello-Filho (2010). In these studies, the graphite: solid paraffin compositions of 75:20, 70:20, 65:20, 60:20, 55:20, 50:20, 45:20, 40:20 and 20:20 $(\% \mathrm{~m} / \mathrm{m})$, and the $\mathrm{Cu}_{3}\left(\mathrm{PO}_{4}\right)_{2}$-Poly percentages of 5, 10, $15,20,25,30,35,40$, and $60 \% \mathrm{~m} / \mathrm{m}$ relating to the total mass of the carbon composite, were evaluated. The carbon composite electrode was initially prepared by mixing $0.40 \mathrm{~g}$ of $\left(\mathrm{Cu}_{3}\left(\mathrm{PO}_{4}\right)_{2}\right.$-Poly $)(40 \%, \mathrm{~m} / \mathrm{m}), 0.40 \mathrm{~g}$ of graphite powder $(40 \%, \mathrm{~m} / \mathrm{m})$, and $0.20 \mathrm{~g}$ of melted paraffin $(20 \%$, $\mathrm{m} / \mathrm{m})$ at $60{ }^{\circ} \mathrm{C}$.

The resulting modified carbon composite was placed in a $1 \mathrm{~mL}$ plastic syringe and a copper wire was inserted to obtain external electric contact. A unmodified carbon composite electrode (UCCE) containing $80 \%(\mathrm{~m} / \mathrm{m})$ graphite and $20 \%(\mathrm{~m} / \mathrm{m})$ solid paraffin was prepare for the purpose of comparing with a modified electrode containing $40 \%$ $(\mathrm{m} / \mathrm{m}) \mathrm{Cu}_{3}\left(\mathrm{PO}_{4}\right)_{2}$-Poly.

Cyclic voltammetry and square wave measurements were performed in $0.10 \mathrm{~mol} \mathrm{~L}^{-1}$ phosphate buffer solution containing $10 \%(\mathrm{v} / \mathrm{v})$ ethanol (conditional $\mathrm{pH}$ of 6.9$)$, and the experiments were carried out by applying a potential sweep between 0.00 and $0.55 \mathrm{~V}$ for cyclic voltammetry and -0.05 and $0.50 \mathrm{~V}$ for square wave voltammetry.

\section{Sample solution preparation}

Samples (solid and liquid) were purchased at local pharmacies. 10 tablets of solid sample were triturated and mixed and $122 \mathrm{mg}$ of powder were dissolved in $10 \mathrm{~mL}$ of
$0.1 \mathrm{~mol} \mathrm{~L}^{-1}$ phosphate buffer solution containing $10 \%(\mathrm{v} / \mathrm{v})$ ethanol (conditional $\mathrm{pH}$ of 6.9). Then, $100 \mu \mathrm{L}$ aliquot of this solution was transferred to the electrochemical cell containing $5 \mathrm{~mL}$ of this supporting electrolyte.

An aliquot of $500 \mu \mathrm{L}$ of liquid sample was transferred to a $10 \mathrm{~mL}$ volumetric flask and diluted with 0.1 mol L ${ }^{-1}$ phosphate buffer solution containing $10 \%(\mathrm{v} / \mathrm{v})$ ethanol (conditional $\mathrm{pH}$ of 6.9). Then, similarly, $100 \mu \mathrm{L}$ aliquot of this solution was transferred to the electrochemical cell containing $5 \mathrm{~mL}$ of supporting electrolyte. The SW voltammograms were obtained after each aliquot addition.

\section{Statistics}

All experiments were carried out in triplicate. All data are presented as means $\pm \mathrm{SD}$. Student's $t$-test at a $95 \%$ confidence level was used. $P<0.05$ was considered a significant result.

\section{RESULTS AND DISCUSSION}

\section{Effect of electrode composition}

The effect of the carbon composite composition on the voltammetric profiles of a $5.0 \times 10^{-6} \mathrm{~mol} \mathrm{~L}^{-1}$ rutin in $0.1 \mathrm{~mol} \mathrm{~L}^{-1}$ phosphate buffer solution containing $10 \%(\mathrm{v} / \mathrm{v})$ of ethanol (conditional $\mathrm{pH}$ of 6.9) was initially evaluated.

The analytical signal (peak currents) increased with increasing amount of chemical modifier up to $40 \%(\mathrm{~m} / \mathrm{m})$. For $\mathrm{Cu}_{3}\left(\mathrm{PO}_{4}\right)_{2}$ amounts higher than $40 \%(\mathrm{~m} / \mathrm{m})$, the analytical signal decreased significantly (results not shown). This event occurred owing to a decrease in the graphite powder content in the composite and the consequent reduction of the conductive electrode area. The highest quality carbon composite structure was found for an electrode composition of $40 \%(\mathrm{~m} / \mathrm{m}) \mathrm{Cu}_{3}\left(\mathrm{PO}_{4}\right)_{2}$-polyester resin, $40 \%(\mathrm{~m} / \mathrm{m})$ graphite, and $20 \%(\mathrm{~m} / \mathrm{m})$ solid paraffin.

\section{Electrode surface characterization}

The modification of electrodes with functional groups, inorganic or biologic catalyst, polymeric films etc., has improved the performance of electrochemical electrode in analytical chemistry. These changes may increase the electrode characteristics such as selectivity, sensitivity and/or operational stability. In this sense, it is fundamental the surface characterization of the electrode surface.

Figure 1 shows the scanning electron micrographs (SEMs) of the modified electrode with $\mathrm{Cu}_{3}\left(\mathrm{PO}_{4}\right)_{2}$ before and after use of the electrode in one hundred of determinations rutin. The micrographs obtained in backscatter-mode 

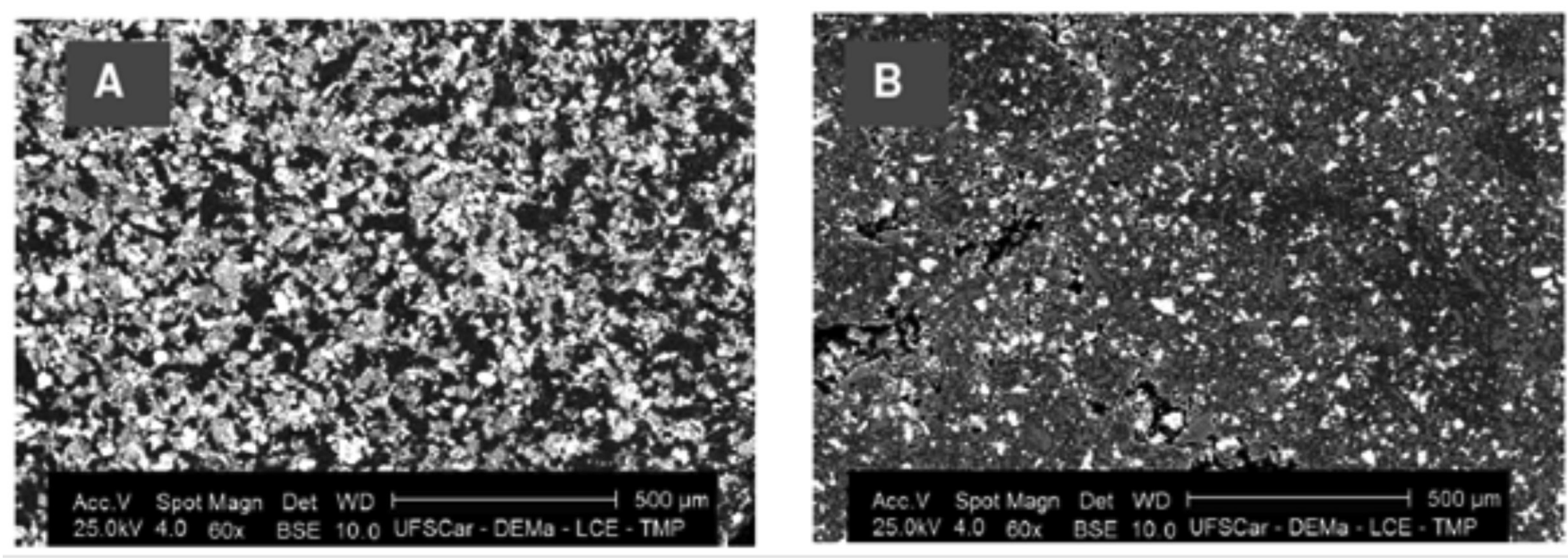

FIGURE 1 - SEM micrographs of MCCE- $\mathrm{Cu}_{3}\left(\mathrm{PO}_{4}\right)_{2}$ surface (A) before and (B) after rutin voltammetric determination in $0.1 \mathrm{~mol}$ $\mathrm{L}^{-1}$ phosphate buffer $10 \%$ ethanol (v/v) $\left(\mathrm{pH}_{\text {cond }} 6.9\right)$; BSE detector; scale: $500 \mu \mathrm{m}$; zoom 60 times.

(BSE) allowed the chemical contrast of the electrode surface; the clearest points indicate the chemical element of higher density, which can be related to copper. In this Figure, it can be seen that the electrode surface is uniform and presented little porous showing a very good homogenization of the components. Thus, this electrode can be classed as dispersion composite in accordance with Cespedes and co-workers (1996) due to conducting material is randomly distributed in the electrode surface. After using the electrode for rutin determination in $0.1 \mathrm{~mol} \mathrm{~L}^{-1}$ phosphate buffer solution (conditional $\mathrm{pH}$ 6.9) containing $10 \%(\mathrm{v} / \mathrm{v})$ of ethanol, the electrode shows regularity of the surface, despite with lower amount of material (compare both images). The final profile, with regularity, can represent suitable operational stability.

Results obtained from EDX (results not shown) indicated that the composition percentage of $\mathrm{Cu}_{3}\left(\mathrm{PO}_{4}\right)_{2}$ onto the surface of electrode was $38.2 \%(\mathrm{~m} / \mathrm{m})$, slightly lower than the $40 \%(\mathrm{~m} / \mathrm{m})$ used in the preparation of the carbon composite. Moreover, the oxygen content was kept constant even after high number of determinations, indicating that the oxide formation in the electrode surface was not favored, resulting in an extraordinary stability and extended lifetime of the electrode.

\section{Effect of supporting electrolyte}

The voltammetric behavior of the modified carbon composite electrode was investigated in five different supporting electrolytes (phosphate buffer, sodium nitrate, potassium nitrate, sodium chloride, and potassium chloride) in several concentrations by cyclic voltammetry (Figure 2 ). The presence of the voltammetric peak was observed in all these supporting electrolytes. Moreover, in phosphate buffer solution the anodic peak current was higher and the peak shape was better defined. Therefore, this buffer solution was selected for further experiments.

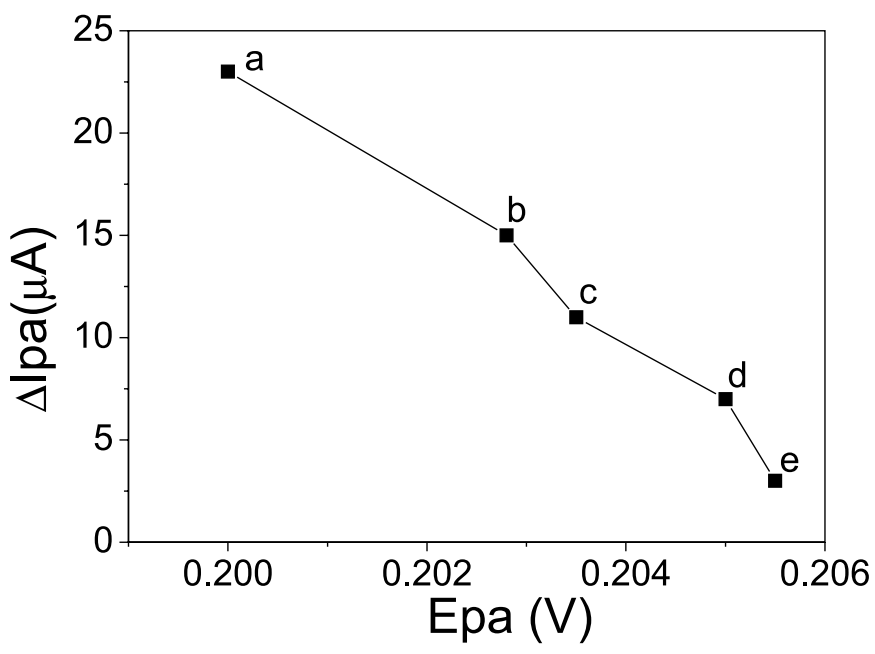

FIGURE 2 - Effect of supporting electrolyte using MCCE$\mathrm{Cu}_{3}\left(\mathrm{PO}_{4}\right)_{2}$ for $4.0 \times 10^{-5} \mathrm{~mol} \mathrm{~L}^{-1}$ rutin in (a) phosphate buffer; (b) potassium nitrate; (c) sodium nitrate; (d) sodium chloride and (e) potassium chloride solutions. Concentration of electrolyte solutions: $0.1 \mathrm{~mol} \mathrm{~L}^{-1} / 10 \%$ ethanol $(\mathrm{v} / \mathrm{v})\left(\mathrm{pH}_{\text {cond }} 6.9\right)$.

The catalytic action of copper has been reported to be the result of $\mathrm{Cu}(\mathrm{II}) / \mathrm{Cu}(\mathrm{I})$ at very high positive potential, or $\mathrm{Cu}(\mathrm{III}) / \mathrm{Cu}(\mathrm{II})$ redox system and a discussion of the potentialities of this redox system has been discussed by Freitas and Fatibello-Filho (2010). Furthermore, some studies have described the influence different factors, such as supporting electrolyte, concentration and $\mathrm{pH}$ of supporting electrolyte, number of donor atoms of the analyte, redox potential of the analyte and voltammetric 

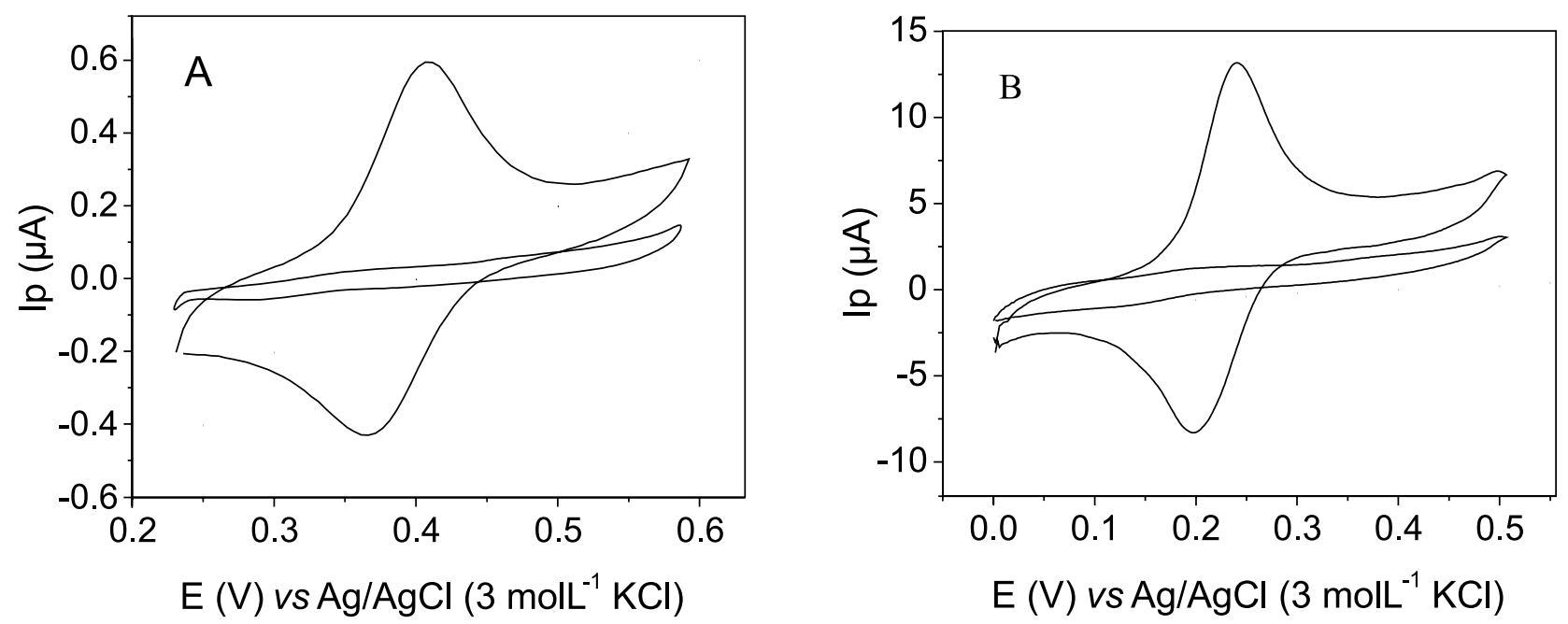

FIGURE 3 - Cyclic voltammograms obtained with (A) UCCE; (B) MCCE-Cu $\left(\mathrm{PO}_{4}\right)_{2}$ in the absence and presence of $4.0 \times 10^{-5}$ mol L $\mathrm{L}^{-1}$ rutin in $0.1 \mathrm{~mol} \mathrm{~L}^{-1}$ phosphate buffer $/ 10 \%$ ethanol $(\mathrm{v} / \mathrm{v})\left(\mathrm{pH}_{\text {cond }} 6.9\right)$; scan rate of $50 \mathrm{mVs}^{-1}$.

parameters, which affect the $\mathrm{Cu}(\mathrm{II}) / \mathrm{Cu}(\mathrm{I})$ couple and/or analytical signal (Domenech et al., 2000; Somasundrum et al., 1996; Vazqueza et al., 1994).

In our study, the voltammetric response of the modified carbon composite electrode with $\left(\mathrm{Cu}_{3}\left(\mathrm{PO}_{4}\right)_{2}\right.$-Poly was not affected by the concentration of the supporting electrolyte. The $0.10 \mathrm{~mol} \mathrm{~L}^{-1}$ phosphate buffer solution was chosen to further experiments.

\section{Effect of $\mathrm{pH}$}

The analytical response of MCCE with $\mathrm{Cu}_{3}\left(\mathrm{PO}_{4}\right)_{2}$ Poly $(40 \% \mathrm{~m} / \mathrm{m})$ was studied over a wide $\mathrm{pH}$ range between 4 to 9 using phosphate buffer solution in the presence and absence of $4.0 \times 10^{-5} \mathrm{~mol} \mathrm{~L}^{-1}$ rutin (results not shown). The peak current increased with increasing $\mathrm{pH}$ from 4.0 to 7.0, but decreased at $\mathrm{pH}$ greater than 7.0, fact attributed to the formation of copper(II) hydroxide at the electrode surface (eq. 1).

$\mathrm{Cu}_{3}\left(\mathrm{PO}_{4}\right)_{2(\mathrm{es})}+6 \mathrm{OH}^{-} \rightleftarrows 3 \mathrm{Cu}(\mathrm{OH})_{2(\mathrm{es})}+2 \mathrm{PO}_{4}^{3-}$

Since the best definition of peak and maximum analytical response were obtained at $\mathrm{pH} 6.9$, this $\mathrm{pH}$ was chosen for optimization of other variables and for the analytical determination of rutin.

\section{Electrochemical characteristics}

Figure 3 shows the cyclic voltammograms obtained using an unmodified carbon composite electrode (UCCE) (A) and a modified carbon composite electrode with $\mathrm{Cu}_{3}\left(\mathrm{PO}_{4}\right)_{2}$-Poly $(40 \% \mathrm{~m} / \mathrm{m})(\mathrm{MCCE})(\mathrm{B})$ in the absence and in the presence of $4.0 \times 10^{-5} \mathrm{~mol} \mathrm{~L}^{-1}$ rutin. It can be seen from these voltammograms that the current peak obtained with MCCE was much higher than that obtained using UCCE (20 times higher) with a decrease of over potential of about $150 \mathrm{mV}$ (from $400 \mathrm{mV}$ to $250 \mathrm{mV}$ ), indicating the existence of an electrocatalytic process. Moreover, the signal/noise was improved at the modified electrode and the possibility from interference of electroactive species present in the sample matrix of interest may be lower.

The MCCE- $\mathrm{Cu}_{3}\left(\mathrm{PO}_{4}\right)_{2}$ presented a reversible behavior for rutin, once presented a ratio of peak currents, $\left(\mathrm{I}_{\mathrm{ap}} / \mathrm{I}_{\mathrm{cp}}\right)$ equal to one and a separation of peak potentials, $\mathrm{E}_{\mathrm{pa}}-\mathrm{E}_{\mathrm{pc}}(\Delta \mathrm{Ep})$ equal to $56 \mathrm{mV}$, according to the accepted theory of cyclic voltammetric (Brett et al., 1993).

A linear plot of the peak current $v s$. the square root of scan rate was obtained, with a 0.999 correlation coefficient for both anodic and cathodic peak, indicating that the rutin oxidation and reduction process was controlled by diffusion (Figure 4) (Brett et al, 1993; Scholz, 2002).

The Ep vs $\mathrm{pH}$ study shows a linear plot with slope of $29.6 \mathrm{mV} \mathrm{pH}^{-1}$ (Figure $5 \mathrm{~A}$ ) indicating that two electrons were involved in the oxidation process at electrode surface. It can also be calculated the electron number involved in the rutin oxidation applying the SWV theory (Krause, 1969; Mirceski et al., 2007; Osteryoung et al., 1985; Ramaley, 1969); which $\Delta \mathrm{Ep} v s \Delta \log f$ (logarithm of frequency) for reversible systems is linear in agreement with equation 2.

$$
\Delta E_{\mathrm{p}} / \Delta \log f=-2.3 \mathrm{RT} / 2 \mathrm{nF}
$$

The slope obtained was $0.0145 \mathrm{~V}$ (from Figure 5B). When substituting this value in the equation 2 , the num- 


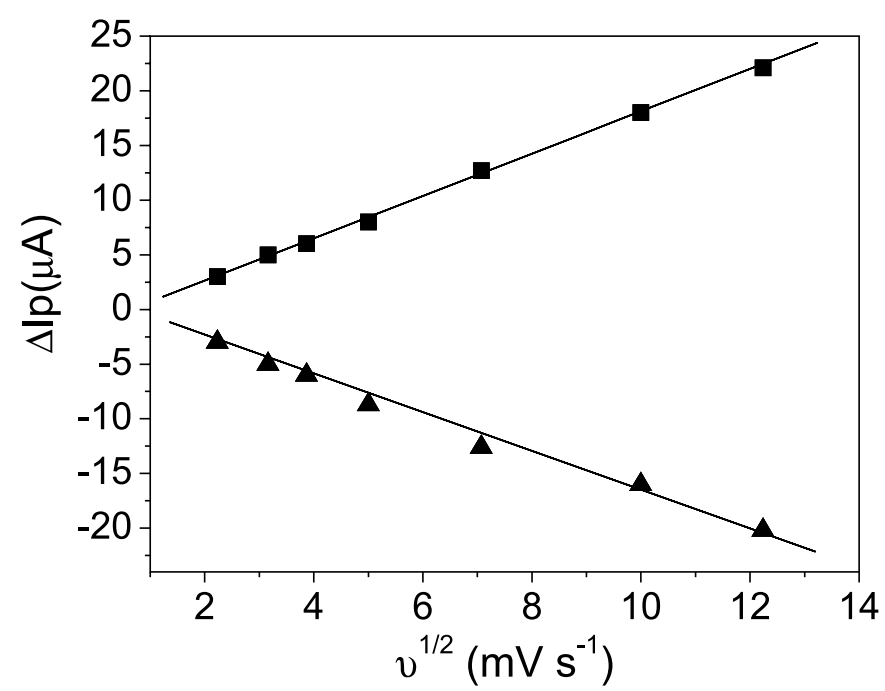

FIGURE 4 - Dependence of the peak current $v s$ square root of the scan rate in supporting electrolyte in the presence of $4.0 \times 10^{-5} \mathrm{~mol} \mathrm{~L}{ }^{-1}$ rutin; $(\boldsymbol{\square})$ anodic peak current and $(\boldsymbol{\Delta})$ cathodic peak current. $\Delta \mathrm{Ip}=$ value of anodic or cathodic peak current subtracted from the value of blank peak current.

ber of was obtained as 2. This result confirms the results obtained in the Ep vs $\mathrm{pH}$ study (Figure 5A).

Thus, considering the Ep vs $\mathrm{pH}$ study and the theory developed for the SWV (Krause, 1969; Mirceski et al., 2007; Osteryoung et al., 1985; Ramaley, 1969) for reversible systems, a plausible mechanism for the voltammetric response of the proposed electrode for rutin is postulated. This mechanism is based on two processes outlined in Figure 6. Initially, a chemical oxidation of the 3',4'-dihydroxy substituent on the B-ring of rutin by $\mathrm{Cu}(\mathrm{II})$ at electrode surface with the formation of 3',4'-diquinone

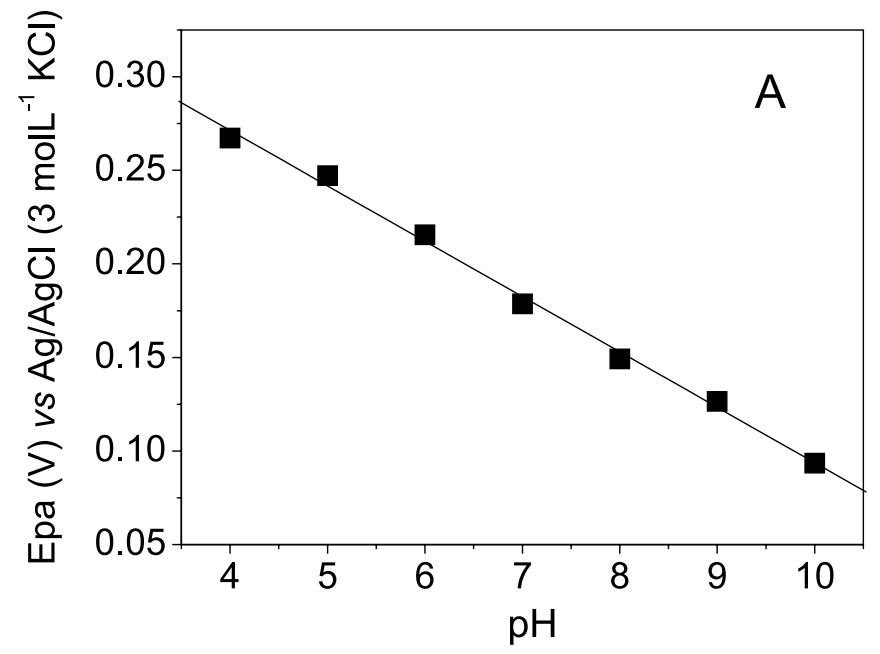

and $2 \mathrm{H}^{+}\left(\mathrm{H}_{3} \mathrm{O}^{+}\right)$and $\mathrm{Cu}(\mathrm{I})$ was observed, followed by an electrochemical process of oxidation of $\mathrm{Cu}(\mathrm{I})$ to $\mathrm{Cu}$ (II).

\section{Optimization of SWV parameters and analytical characteristics}

The peak current obtained in square-wave voltammetry depends on various instrumental parameters such as the square-wave frequency $(f)$, scan increment $\left(\Delta E_{\mathrm{s}}\right)$ and square-wave amplitude $(a)$. These parameters are interrelated and have a combined influence on peak current response. The influence of these instrumental parameters on the peak current response of $4.0 \times 10^{-5} \mathrm{~mol} \mathrm{~L}^{-1}$ rutin in $0.10 \mathrm{~mol} \mathrm{~L}^{-1}$ phosphate buffer $/ 10 \%$ ethanol (v/v) (conditional $\mathrm{pH}$ 6.9) was investigated. Table I shows the SWV parameters studied and the optimum values obtained for rutin determination. A baseline increase was observed when the frequency was increased. Thus, a $f$ value of $50 \mathrm{~s}^{-1}$ was selected for all determinations due to a stable baseline and higher voltammetric signal obtained.

Pulse amplitude $(a)$ is another parameter that strongly influences the peak current in square-wave voltammetry. A better voltammetric definition of peak current was observed in $a$ value of $40 \mathrm{mV}$, which was chosen for the subsequent analytical applications.

The effective rate of potential variation in squarewave voltammetry is the product between $f$ and $\Delta E_{\mathrm{s}}$. The latter parameter will also increase the signal and, therefore, the sensitivity of the technique (Mirceski et al., 2007; Osteryoung et al., 1985). However, for large values of $\Delta E_{\mathrm{s}}$, a broadening of the peaks may occur, thus diminishing the resolution of the determinations. In this work, for the analytical applications, $\Delta E_{\mathrm{s}}$ was set at $1 \mathrm{mV}$.

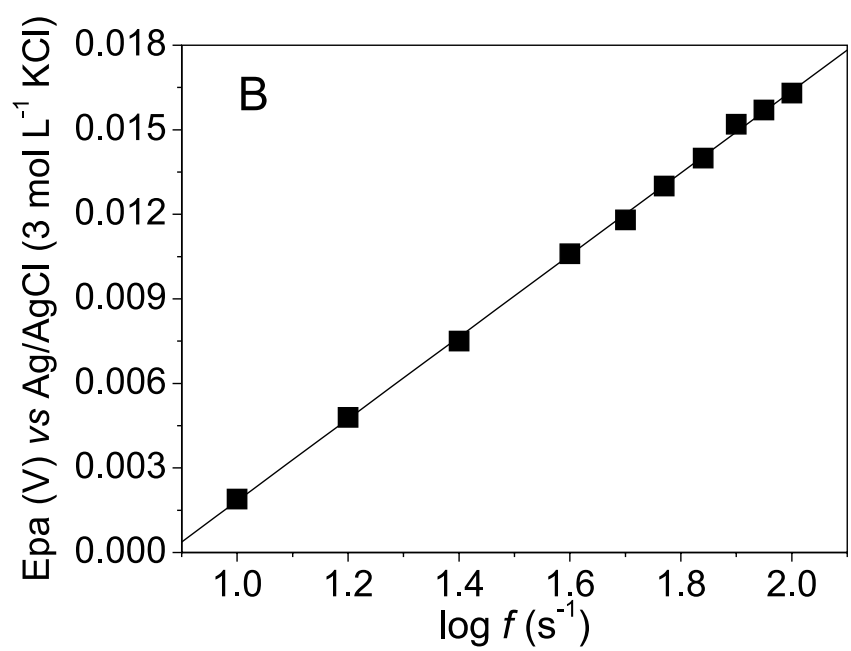

FIGURE 5 - (A) Epa vs pH and (B) Epa vs $\log f$ studies. 


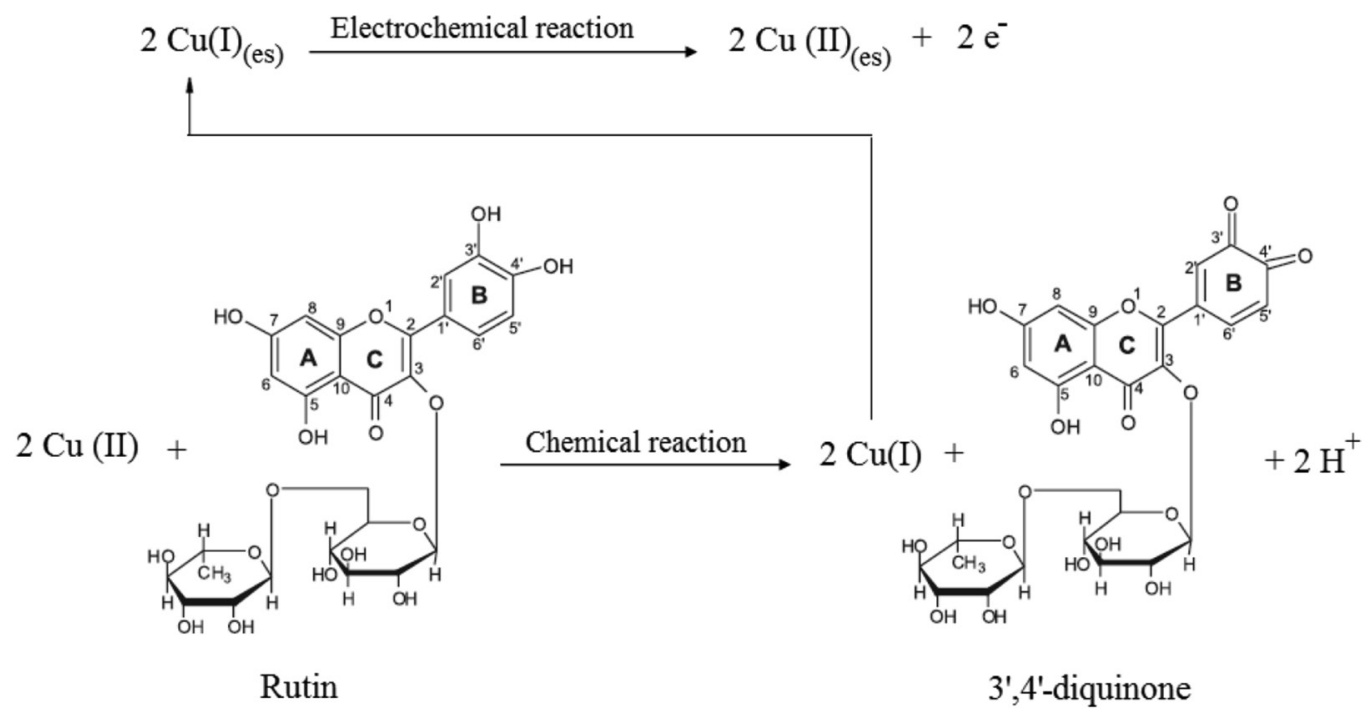

FIGURE 6 - Proposed mechanism for the determination of rutin at $\mathrm{MCCE}-\mathrm{Cu}_{3}\left(\mathrm{PO}_{4}\right)_{2}$ electrode surface.

TABLE I - Investigated square wave voltammetry (SWV) parameters and their optimum values for the determination of rutin

\begin{tabular}{ccc}
\hline \multicolumn{3}{c}{ Rutin } \\
\hline Parameter & Studied range & Optimum value \\
\hline SW frequency $(f)$ & $10-100 \mathrm{~s}^{-1}$ & $50 \mathrm{~s}^{-1}$ \\
SW amplitude $(a)$ & $10-100 \mathrm{mV}$ & $40 \mathrm{mV}$ \\
Scan increment $\left(\Delta E_{\mathrm{s}}\right)$ & $1-5 \mathrm{mV}$ & $1 \mathrm{mV}$ \\
\hline
\end{tabular}

The effect of several species, such as sodium saccharine, methylparaben, starch, calcium carbonate and magnesium stearate using the $\mathrm{MCCE}-\mathrm{Cu}_{3}\left(\mathrm{PO}_{4}\right)_{2}$ electrode in the presence of $4.0 \times 10^{-6} \mathrm{~mol} \mathrm{~L}^{-1}$ rutin solution in the supporting electrolyte was evaluated in 1:1 and 10:1 concentration ratio (interference species: rutin).

Addition-recovery experiments were also performed, and the results (Table II) show that average recoveries varied from 98.2 to $104 \%$, demonstrating the accuracy of the proposed method. It is important to note that the concomitants present in this sample did not cause important matrix interferences for the samples analyzed by the proposed method.

Under optimized conditions shown in Table I, the SW voltammograms for different rutin concentrations were obtained and are presented in Figure 7. As shown in the insert of this Figure, the analytical curve was linear in rutin concentration range from $9.9 \times 10^{-8}$ to $2.5 \times 10^{-6} \mathrm{~mol} \mathrm{~L}^{-1}$, with a detection limit (three times the standard deviation of signal blank/slope) of $1.2 \times 10^{-8} \mathrm{~mol} \mathrm{~L}^{-1}$. The linear regression equation was: $(\Delta \mathrm{Ipa} / \mathrm{A})=7.36 \times 10^{-7}$
TABLE II - Results of recoveries of rutin standard solution in pharmaceuticals using the proposed electrode

\begin{tabular}{lccc}
\hline \multirow{2}{*}{ Sample } & \multicolumn{2}{c}{ Rutin $\left(\mathrm{mg} \mathrm{L}^{-1}\right)$} & \multirow{2}{*}{ Recovery \% } \\
\cline { 2 - 3 } & Added & Found & \\
\hline \multirow{3}{*}{ A } & 2.30 & $2.37 \pm 0.07$ & 103 \\
& 3.50 & $3.48 \pm 0.06$ & 99.4 \\
& 5.20 & $5.41 \pm 0.09$ & 104 \\
\hline \multirow{2}{*}{ B } & 2.30 & $2.26 \pm 0.03$ & 98.2 \\
& 3.50 & $3.50 \pm 0.04$ & 100 \\
\hline
\end{tabular}

$n=3$

+5.40 [Rutin], $r=0.9994)$, where $\Delta$ Ipa is the analytical signal minus the background current and [Rutin] is rutin concentration in $\mathrm{mol} \mathrm{L}^{-1}$.

Table III shows the analytical characteristics such as work potential $(\mathrm{mV})$, linear range of the analytical curve $\left.(\mathrm{mol} \mathrm{L})^{-1}\right)$ and the limit of detection $\left(\mathrm{mol} \mathrm{L}^{-1}\right)$ of the electrode described in this work in relation to those electrodes reported in the literature (Franzoi et al., 2008; Santos et al., 2008; Sun et al., 2008; Chen et al., 2010; Yang et al., 2010; Freitas et al., 2009). As can be observed from this Table, the proposed electrode exhibited a low working potential relation to those reported in the literature, an analytical calibration curve for the low concentration range, detection limits lower than those reported in this Table.

On a comparison with our previous studies for rutin determination in pharmaceutical formulations using a different electrode (carbon paste electrode modified with 


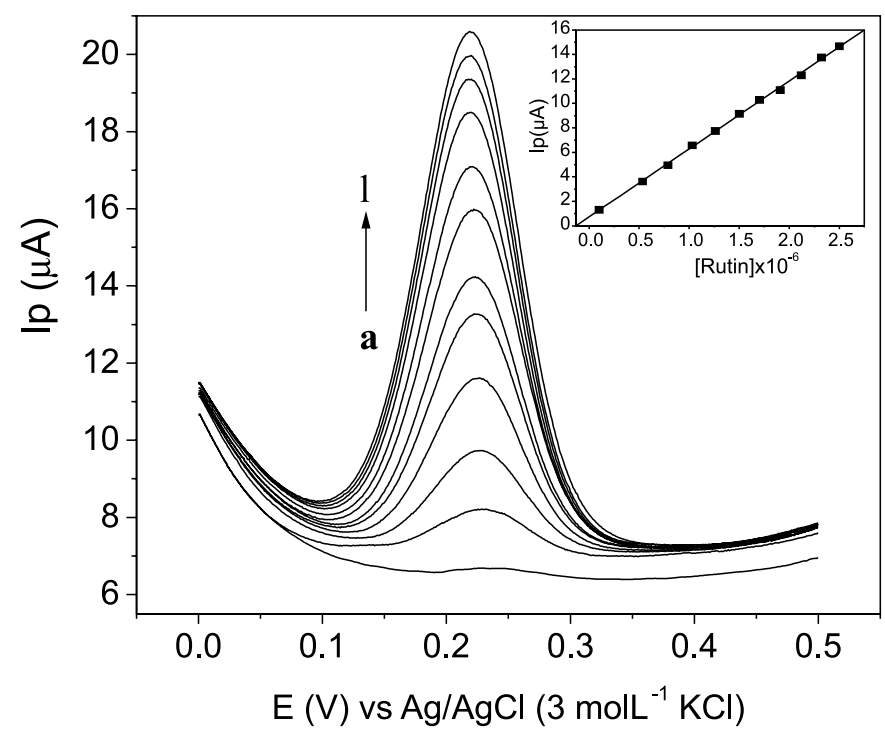

FIGURE 7 - (A) SW voltammograms for various concentrations of rutin; (a) supporting electrolyte; (b) $9.97 \times 10^{-8}$; (c) $5.34 \times 10^{-7}$; (d) $7.86 \times 10^{-7}$; (e) $1.03 \times 10^{-6}$; (f) $1.26 \times 10^{-6}$; (g) $1.50 \times 10^{-6}$; (h) $1.70 \times 10^{-6}$; (i) $1.91 \times 10^{-6}$; (j) $2.12 \times 10^{-6}$; (k) $2.32 \times 10^{-6} \mathrm{~mol} \mathrm{~L}^{-1}$; (l) $2.50 \times 10^{-6} \mathrm{~mol} \mathrm{~L}^{-1}$; using MCCE$\mathrm{Cu}_{3}\left(\mathrm{PO}_{4}\right)_{2}$ in $0.1 \mathrm{~mol} \mathrm{~L}^{-1}$ phosphate buffer $/ 10 \%$ ethanol (v/v) $\left(\mathrm{pH}_{\text {cond }} 6.9\right)$; the inset presents the analytical curve. cation-exchange resin) (Freitas et al., 2009), the present study offered some advantages, such as: the higher concentration of linear range, extended lifespan of 15 months (around 2,000 determinations), and simple building method (fewer stages of fabrication of electrode) what also imply less total cost of the method proposed.

The repeatability $(n=10)$ and reproducibility (five different days) were determined by using a standard solution of rutin, $4.0 \times 10^{-5} \mathrm{~mol} \mathrm{~L}^{-1}$. Between each voltammetric measurement, the surface of the electrode was not renewed. The relative standard deviations were less than $1 \%$ and $2 \%$, respectively.

\section{Analysis of pharmaceutical formulations}

Table IV shows the results obtained using a HPLC, comparative method for the determination of rutin in pharmaceutical formulations, the proposed voltammetric method and label value. The statistical calculations for the assay results showed good accuracy of the method according to the t-test $\left(t_{\text {exp }}=2.234<t_{\text {label }}=2.571\right)$. Thus, there are no significant differences between the results obtained by either procedure at the $95 \%$ confidence level, indicating

TABLE III - Values of work potential, linear range and limit of detection obtained in several voltammetric methods

\begin{tabular}{|c|c|c|c|c|}
\hline $\mathrm{Ep}(\mathrm{mV})$ & Linear range $\left(\mathrm{mol} \mathrm{L}^{-1}\right)$ & $\mathrm{LD}\left(\mathrm{mol} \mathrm{L}^{-1}\right)$ & LD solutions* & Ref \\
\hline 870 & $3.9 \times 10^{-7}-1.3 \times 10^{-5}$ & $1.5 \times 10^{-7}$ & $\begin{array}{c}0.1 \mathrm{~mol} \mathrm{~L}^{-1} \\
\text { phosphate buffer (pH 6.0) }\end{array}$ & (Franzoi et al. 2008) \\
\hline 370 & $5.0 \times 10^{-8}-5.0 \times 10^{-7}$ & $1.8 \times 10^{-8}$ & $\begin{array}{l}\text { Britton-Robinson buffer } \\
(\mathrm{pH} \mathrm{4.0)}\end{array}$ & (Santos et al. 2008) \\
\hline 448 & $5.0 \times 10^{-8}-5.0 \times 10^{-7}$ & $3.6 \times 10^{-7}$ & $0.1 \mathrm{~mol} \mathrm{~L}^{-1} \mathrm{PBS}(\mathrm{pH} 2.5)$ & (Sun et al. 2008) \\
\hline 440 & $2.5 \times 10^{-7}-1.0 \times 10^{-5}$ & $1.0 \times 10^{-7}$ & $0.1 \mathrm{~mol} \mathrm{~L}^{-1} \mathrm{PBS}(\mathrm{pH} 4.0)$ & (Chen et al. 2010) \\
\hline 487 & $4.8 \times 10^{-8}-9.6 \times 10^{-7}$ & $3.2 \times 10^{-8}$ & $\begin{array}{c}0.1 \mathrm{~mol} \mathrm{~L}^{-1} \\
\text { phosphate buffer ( } \mathrm{pH} 3.5 \text { ) }\end{array}$ & (Yang et al. 2010) \\
\hline-50 & $9.9 \times 10^{-7}-8.0 \times 10^{-6}$ & $2.6 \times 10^{-8}$ & $\begin{array}{c}0.10 \mathrm{KNO}_{3} / 10^{-6} \mathrm{HNO}_{3} \\
\mathrm{~mol} \mathrm{~L}^{-1}(\mathrm{pH} 6.0)\end{array}$ & (Freitas et. al, 2009) \\
\hline 190 & $9.9 \times 10^{-8}-2.5 \times 10^{-6}$ & $1.2 \times 10^{-8}$ & $\begin{array}{c}0.1 \mathrm{~mol} \mathrm{~L}^{-1} \text { phosphate } \\
\text { buffer / } 10 \% \text { ethanol (v/v) } \\
\left(\mathrm{pH}_{\text {cond }} 6.9\right) \\
\end{array}$ & This work \\
\hline
\end{tabular}

$\mathrm{Ep}=$ work potential; $\mathrm{LD}=$ Limit of detection; Ref = Reference; LD solutions* = solutions where the limit of detection was estimated; PBS = phosphate buffer saline

TABLE IV - Determination of rutin in pharmaceutical formulations by voltammetric and HPLC methods

\begin{tabular}{cccccc}
\hline \multirow{2}{*}{ Sample } & \multicolumn{2}{c}{ Rutin } & SWV & $\mathrm{E}_{\mathrm{r} 1} \%$ & $\mathrm{E}_{\mathrm{r} 2} \%$ \\
\cline { 2 - 5 } & Label value & HPLC & $306 \pm 1$ & +2.0 & +2.3 \\
$\mathrm{~A}$ & 300 & $299 \pm 2$ & $19.7 \pm 0.2$ & -1.5 & -1.0 \\
\hline
\end{tabular}

$n=3$; confidence level of $95 \% ; \mathrm{A}=\mathrm{mg}$ of rutin per tablet; $\mathrm{B}=\mathrm{mg}$ of rutin per milliliter; $E_{r 1 \%}=$ voltammetric method versus label value; $E_{r 2 \%}=$ voltammetric method versus HPLC method. 
that the modified carbon composite electrode is suitable for the determination of rutin in pharmaceuticals.

\section{CONCLUSIONS}

The modified carbon composite electrode with $\mathrm{Cu}_{3}\left(\mathrm{PO}_{4}\right)_{2}$ immobilized in a polyester resin showed to be a very suitable method for the determination of rutin in real samples. The use of less positive electrode potential improved the applicability of the proposed method.

The proposed method is versatile, robust and environmentally-friendly since it requires the use of immobilized material. It is an interesting strategy for avoiding or minimizing environmental contamination. In view of the low-cost of the proposed method, it is feasible for large-scale analysis and/or for quality assurance of pharmaceutical formulations, drugs, food, and other samples.

The results obtained using the proposed MCCE$\mathrm{Cu}_{3}\left(\mathrm{PO}_{4}\right)_{2}$ electrode for determination of rutin in pharmaceutical samples are in close agreement with those obtained using the HPLC method at a $95 \%$ of confidence level, showing its practical feasibility.

Moreover, the proposed method offers the advantages of reliability, simplicity of the fabrication of modified electrode, good precision, and low cost.

\section{ACKNOWLEDGMENTS}

The authors gratefully acknowledge financial support from Brazilian foundations (FAPESP, CAPES, CNPq and Mobility Academic Program-Teachers scale (AUGM).

\section{REFERENCES}

BRETT, A.M.O.; BRETT, C.M.A. Electroquímica: princípios, métodos e aplicações. New York: Oxford University Press, 1993. $471 \mathrm{p}$.

BRETT, A.M.O.; GHICA, M.E. Electrochemical oxidation of quercetin. Electroanal., v.15, p.1745-1750, 2003.

CESPEDES, F.; MARTINEZ-FABREGAS, E.; ALEGRET, S. New materials for electrochemical sensing-rigid conducting composites. Trac-. Trends Anal. Chem., v.15, p.296-304, 1996.

CHEN, G.; ZHANG, H.; YE, J. Determination of rutin and quercetin in plants by capillary electrophoresis with electrochemical detection. Anal. Chim. Acta, v.423, p.69$76,2000$.
CHEN, X.; WANG, Z.; ZHANG, F.; ZHU, L.; LI, Y.; XIA, Y. Determination of rutin on the poly $(p$-aminobenzene sulfonic acid) modified glassy carbon electrode. Chem. Pharm. Bull., v.58, p.475-478, 2010.

DAPKEVICIOUS, A.; BEEK, T.A.V.; NIEDERLANDER, H.A.G.; GROOT, A.D. On-Line detection of antioxidative activity in High-Performance Liquid Chromatography eluates by chemiluminescence. Anal. Chem., v.71, p.736$740,1999$.

DOMENECH, A.; GARCIA-ESPANA, E.; LUIS, S.V.; MARCELINO, V.; MIRAVET, J.F. Electrochemistry of copper complexes with polyaza[n]paracyclophanes. Influence of ATP as an exogen ligand on the relative stability of the $\mathrm{Cu}(\mathrm{II})$ and $\mathrm{Cu}(\mathrm{I})$ oxidation states. Inorg. Chim. Acta, v.299, p.238-246, 2000.

ERLUND, I.; KOSONEN, T.; ALFTHAN, G.; MÄENPÄÄ, J.; PERTTUNEN, K.; KENRAALI, J.; PARANTAINEN, J.; ARO, A. Pharmacokinetics of quercetin from quercetin aglycone and rutin in healthy volunteers. Eur. J. Clin. Pharmacol., v.56, p.545-553, 2000.

FATIBELLO-FILHO, O; VIEIRA, I.C. Construction and analytical application of a biosensor based on stearic acidgraphite powder modified with sweet potato tissue in organic solvents. Fresen. J. Anal. Chem., v.368, p.338-343, 2000.

FRANZOI, A.C.; MIGOWSKI, P.; DUPONT, J.; VIEIRA, I.C. Development of biosensors containing laccase and imidazolium bis(trifluoromethylsulfonyl)imide ionic liquid for the determination of rutin. Anal. Chim. Acta, v.639, p.90-95, 2009.

FRANZOI, A.C.; SPINELLI, A.; VIEIRA, L.C. Rutin determination in pharmaceutical formulations using a carbon paste electrode modified with poly (vinylpyrrolidone). $J$. Pharm. Biomed. Anal., v.47, p.973-977, 2008.

FREITAS, K.H.G.; FATIBELLO-FILHO, O. Carbon composite electrode modified with copper (II) phosphate immobilized in a polyester resin for voltammetric determination of catechin in teas. Anal. Lett., v.43, p.1-14, 2010.

FREITAS, K.H.G.; FATIBELLO-FILHO, O. Simultaneous determination of butylated hydroxyanisole (BHA) and butylated hydroxytoluene (BHT) in food samples using a carbon composite electrode modified with $\mathrm{Cu}_{3}(\mathrm{PO} 4)_{2}$ immobilized in polyester resin. Talanta, v.81, p.1102-1108, 2010. 
FREITAS, K.H.G.; MEDEIROS, R.A.; FATIBELLO-FILHO, O. Voltammetric determination of rutin using a carbon composite electrode modified with copper(II)-resin. Anal. Lett., v.42, p.881-897, 2009.

GENE, R.M.; CARTANA, C.; ADZET, T.; MARIN, E.; PANELLA, T.; CANIGUERAL, S. Anti-Inflammatory and analgesic activity of baccharis trimera: identification of its active constituents. Planta Med., v.62, p.232-235, 1996.

GHICA, M.E.; BRETT, A.M.O. Electrochemical oxidation of rutin. Electroanal., v.17, p.313-318, 2005.

HE, J.; WANG, Y.; DENG, N.; ZHAB, Z.; LIN, X. Cyclic voltammograms obtained from the optical signals: study of the successive electro-oxidations of rutin. Electrochim. Acta, v.52, p.6665-6672, 2007.

HE, J.; WANG, Y.; DENG, N.; LIN, X. Study of the adsorption and oxidation of antioxidant rutin by cyclic voltammetryvoltabsorptometry. Bioelectrochemistry, v.71, p.157-163, 2007.

JANEIRO, P.; BRETT, A.M.O. Catechin electrochemical oxidation mechanisms. Anal. Chim. Acta, v.518, p.109$115,2004$.

KRAUSE, M.S.; RAMALEY, L. Analytical application of square wave voltammetry. Anal. Chem., v.41, p.1365-1369, 1969.

LI, C.H.; CHEN, A.J.; CHEN, X.F.; CHEN, X.G.; ZU, Z.D. Separation and simultaneous determination of rutin, puerarin, daidzein, esculin and esculetin in medicinal preparations by non-aqueous capillary. J. Pharm. Biomed. Anal., v.39, p.125-131, 2005.

LIU, X.H.; LI, L.; ZHAO, X.P.; LU, X.Q. Electrochemical behavior of rutin on a multi-walled carbon nanotube and ionic liquid composite film modified electrode. Colloids Surf. B., v.81, p.344-349, 2010.

MIRCESKI, V.; KOMORSKY-LOVRIC, S.; LOVRIC, M. Square-wave voltammetry: theory and application. Berlin: Springer, 2007. $201 \mathrm{p}$.

NUENGCHAMNONG, N.; LOKKERBOL, A.H.; INGKANINAN, K. Separation and detection of the antioxidant flavonoids, rutin and quercetin, using hplc coupled on-line with colorimetric detection of antioxidant activity. Naresuan U. J., v.12, p.25-37, 2004.
OSTERYOUNG, J.G.; OSTERYOUNG, R.A. Square wave voltammetry. Anal. Chem., v.57, p.101A-110A, 1985.

PACKER, L. Handbook of antioxidants. Oxidative stress and disease. Los Angeles: CRC Press, 2001.91 p.

PEREIRA, A.C.; SANTOS, A.S.; KUBOTA, L.T. Tendências em modificações de eletrodos amperométricos para aplicações analíticas. Quím. Nova, v.25, p.1012-1021, 2002.

PEREIRA, A.V.; FATIBELLO-FILHO, O. Flow injection spectrophotometric determination of L-ascorbic acid in pharmaceutical formulations with on-line solid-phase reactor containing copper (II) phosphate. Anal. Chim. Acta, v.366, p.55-62, 1998.

RAMALEY, L.; KRAUSE, M.S. Theory of square wave voltammetry. Anal. Chem., v.41, p.1362-1365, 1969.

SANTOS, S.X.D.; MAZO, L.H.; CAVALHEIRO, E.T.G. The use of a graphite-silicone rubber composite electrode in the determination of rutin in pharmaceutical formulation. J. Braz. Chem. Soc., v.19, p.1600-1606, 2008.

SCHOLZ, F. Electroanalytical methods: guide to experiments and applications. New York: Springer, 2002. 331 p.

SOMASUNDRUM, M.; KIRTIKARA, K.; TANTICHAROEN, M. Amperometric determination of hydrogen peroxide by direct and catalytic reduction at a copper electrode. Anal. Chim. Acta, v.319, p.59-70, 1996.

SUN, W.; YANG, M.; LI, Y.; JIANG, Q.; LIU, S.; JIAO, K. Electrochemical behavior and determination of rutin on a pyridiniumbased ionic liquid modified carbon paste electrode. J. Pharm. Biom. Anal., v.48, p.1326-1331, 2008.

VAZQUEZA, M.V.; SANCHEZA, S.R.; CALVOB, E.J.; SCHIFFRINC, D.J. The electrochemical reduction of oxygen on polycrystalline copper in borax buffer. $J$. Electroanal. Chem., v.374, p.189-197, 1994.

VOLIKAKIS, G.J.; EFSTATHIOU, C.E. Determination of rutin and other flavonoids by flow-injection/adsorptive stripping voltammetry using nujol-graphite and diphenylethergraphite paste electrodes. Talanta, v.51, p.775-785, 2000. 
WANG, Q.J.; DING, F.; LI, H.; HE, P.G.; FANG, Y.Z. Determination of hydrochlorothiazide and rutin in Chinese herb medicines and human urine by capillary zone electrophoresis with amperometric detection. J. Pharm. Biomed. Anal., v.30, p.1507-1514, 2003.

XU, J.; ZHANG, H.; CHEN, G. Carbon nanotube/polystyrene composite electrode for microchip electrophoretic determination of rutin and quercetin in Flos Sophorae Immaturus. Talanta, v.73, p.932-937, 2007.
YANG, S.L.; QU, L.B.; LI, G.; YANG, R.; LIU, C.C. Gold nanoparticles/ ethylenediamine/carbon nanotube modified glassy carbon electrode as the voltammetric sensor for selective determination of rutin in the presence of ascorbic acid. J. Electroanal. Chem., v.645, p.115-122, 2010.

ZU, Y.; LI, C.; FU, Y.; ZHAO, C. Simultaneous determination of catechin, rutin, quercetin kaempferol and isorhamnetin in the extract of sea buckthorn (Hippophae rhamnoides L.) leaves by RP-HPLC with DAD. J. Pharm. Biomed. Anal., v.41, p.714-719, 2006.

Received for publication on $13^{\text {th }}$ January 2012 Accepted for publication on $20^{\text {th }}$ July 2012 